\title{
PRUKADES (FEATURED PRODUCT OF RURAL AREA) IN INCREASING HOME INDUSTRY PRODUCTIVITY IN PAMEKASAN
}

\author{
Ahmad Rajaul Masrur, Hajjatul Mabbruroh, Darwis \\ STIE Bakti Bangsa Pamekasan \\ masrur.ahmad18@gmail.com
}

\begin{abstract}
Low productivity in home industry which produces featured product in rural area in Pamekasan cannot cover entire market target nationally or internationally. Featured Product of Rural Area (PRUKADes) is the first program of 4 priority planned by Ministry of Village, Disadvantaged Regions and Trasmigration (Kemendes PDTT) aims to increase village competitiveness and company's productivity in order the villagers gain higher income. Based on the statistic analytical test, a result is valid if $r$ is bigger than $r$ in table. In addition, data is considered reliable because the value of Cronbach's Alpha is 0,77 or more than 0,6. From double linear regression analysis, the value is 0,800. It shows that there is a strong relationship between home industry productivity $(X)$ through $X 1$ (workers quality), X2 (managing skill), and X3 (Input and Output process) and the increasing featured product of rural area in Pamekasan $(Y)$. The value is $64,0 \%$ and it is quite big. The rest is 36,0\% and it is influenced by other factors that excluded from this research. Entirely, the research is done by $F$ test $F$ (ensemble regressed coefficient); that is, there is a relationship between home industry productivity $(X)$ and the increase of featured product in rural area in Pamekasan (Y)
\end{abstract}

Keywords : PRUKADes, Village, Home Industry, Productivity

\section{INTRODUCTION}

Indonesian government have improved the development of village through featured product of rural area (PRUKADes) in order to increase village competitiveness, strengthen village development and increase the productivity of joint venture company to gain villagers' higher income including regions's income. To advance PRUKADes, the government does some strategies such as networking between home industry and company. This network ensures that it will be continuing to gain better income for the villagers.

Featured product in Pamekasan mostly is run by home industry or Usaha Roma'an (Madurese) like kripik tette (cassava crisp) and cassava snack in Taro' an village and Larangan Slampar in subdistrict of Tlanakan, rengginang (snack from sticy rice) and teri krispy (crispy billis), pettis ikan (fish paste) in subdistrict Pademawu, original batik of Pamekasan in the capital of Pamekasan and once being a trend in Toronan village, Pamekasan and many more. From some featured product in Pamekasan, up to now there is no progress. The level of home industry productivity which produce featured product in rural area is influenced by some factors such as labour quality, management skill and process of input and output. The better the factors the better the product produced. besides that marketing is also that it continues to play an important role in corporate strategy in some companies indicating that there is an opportunity and taking a real approach to building marketing competence as a source of competitive advantage (Fahrurrozi, 2016) Therefore, this research focuses on PRUKADes (featured product of rural area) 
in increasing home industry productivity to be better.

The problems faced by the businessmen in producing featured product in Pamekasan is the lows of productivity in producing featured product in rural area. The business has not reach market target either nationally or internationally. An indicator is the quality of labor who are mostly unskilled in applying technology, particularly Emarketing. They also do not comprehend the good system of management and the process of input and output as well. Based on the reference above, this research aims to discover the relationship between the increase of featured product in rural area and the level of productivity of home industry in Pamekasan.

\section{LITERATURE REVIEW}

\subsection{The Concept of Village Development}

The development of village is a concept of region development concept either in region or in province. That is, the context of village is larger because it is including society, economy, market access and politics. It also has relationship with other village, subdistrict, district, and its interrelation (Nurman, 2015). in the regulation of Ministry of Village, Disadvantaged Regions and Tramigrassion number 3/2015 about village accompaniment, Phase 1 verse 9 that village development is an attempt of progressing.

The concept of village development planning consist of 5 pillars; they are: village spatial, economy of the village, village culture, disaster mitigation, and environment. Village spatial consist of rehabilitation, reconstruction and development. In addition, the spatial is able to accommodate the need of village spatial improvement in the future through land consolidation (Regulation number 2/2005). In employment of village development, it must refers to the objective that is villagers who are independent, progressive, prosperous, and fair (Raharjo, 2006). village development is a form of implementation UU No. 6/ 2014 about village management that is employed systematically, consistently, and sustainable through facilitating, supervising and accompanying.

\subsection{Featured Product of Rural Area (PRUKADES)}

Featured Product of Rural Area (Prukades) is a high quality product of a village to move and develop its economy. The aims is to develop the local economy and entrepreneurship either in existing business or start-up (decided by Ministry of Village, Disadvantaged Regions and Transmigration number 83/2017 about general guidance of village innovation program). Indonesian government allocates village budget (DD) through Ministry of Village, Disadvantaged Regions and Transmigration (Mendes PDTT) to lead the progress and the competitiveness of the village. Mendes PDTT plans four priority program in developing the villange, they are: 1) sport facility, 2) Bumdesa (a business entity run by the villagers), 3) PRUKADes 4) a village pond.

Featured product of rural area (Prukades) is a form of cooperation intervillage under a businessmen supervision. There are 343 Prukades right now. They are spreading in 148 regions in 29 provinces in Indonesia. It is noted that 18 commodities under 30 companies supervision (Kementerian Desa PDPT, 2019)

\subsection{Government Role in realizing PRUKADes}

The rules of Ministry of Domestic affair Number 37/2007 about guidance of management of village finance. Local government has board authority in managing their region. One of government concern to local development is particular development fund stated in regional income and expenditure budget (APBD) to develop rural area, that is allocation of village funds (ADD) (Sumaryadi, 2005). Ministry of Village, Disadvantaged Regions and Transmigration (Mendes PDTT) realizes the rules number 19/2017 about priority determination of establishment village funds in 2018 Chapter III Phase 4 verse 3 that "Program and activity refers to verse (2) are 
producing featured product in rural area, BUMDesa atau BUMDesa bersama, village ponds, and sport facilities based on the village needs". Based on this rules, the local government manage it seriously to make better life and prosperous for the villagers.

The village policy in implementing the rules of PDTT is strong to force the application of UU No 6/22 about rural area. The duty and the role of local government is socializing and making aware the villagers as the representative district government or province about the importance of BUMDes (Business entity of village) and the activity of PURKADes (featured product of rural area) for villagers' prosperity. BUMDes as social institution has to take society side through its contribution in providing social services. As commercial institution, it aims to get financial profit through local resource (stuff and service) to market. The further rules is through local rules (Perda) and village rules (Perdes) to legitimate the establishment of BUMDes and Purkades. By this rules, local government motivates the society, make them aware and prepare them to develop their own life.

\subsection{Industry}

Home in English is a place to live and industry means a business produces product/service. Home Industry is a small business based on at home. Although it is small but it has economic value (Susana, 2012). the definition of small business is clarified in UU No. 9/1995, states that small business is a economical activity with assets less than Rp. 200 millions (excluded land and buliding in which the activity is run) with profit maximum Rp1.000.000.000.

Meanwhile in Undang-undang No. $20 / 2008$ that small business is an independent productive economy activity done by individual or business entity that is not a company or a branch of the company that possess, monopolize, or as a part of either directly or indirectly- medium or big business.

\subsection{Productivity}

Productivity is a concept describes the relationship between the result (the sum of the stuff and/or service produced) with resource (the number of labor, capital, land, energy, etc.) (Daryanto, 2012). Productivity is a comparison between output and input and how to utilize the resources either in producing the stuff of service (Hasibuan, 2005). Productivity concept can be seen through 2 dimensions, individual and organization. A studies of individual dimension see productivity particularly its relationship with personal characteristics. In this context, the essence of productivity is mental awareness on how life must be better, today and tomorrow.

According to Wignjosoebroto (2000) Productivity in general can be formed as: Productivity $=$ Output/input (measurable)+ input (invisible). Invisible input consists of knoeledge, technical skill, work method and oraganization mnagement, and work motivation. So, in this research productivity valiable is $\mathrm{X} 1=$ labour quality (knowledge level), $\mathrm{X} 2=$ management skill (motivation and organization management) and $\mathrm{X} 3=$ Process of Input and Output (technical management and work method).

\section{RESEARCH METHOD}

This research is run in some villages produce the featured product in Pamekasan such as the capital of Pamekasan, Tlanakan and Pademawu. This research is done in six months, by using primary and secondary data. The primary data is got from the questionnaires for the respondents, meanwhile the secondary data is taken from related institutions, references such as books, journals and internet.

The method in collecting data uses stratified random sampling, that is the respondents are chosen based on their knowledge and skill and their home industry capacity to synchronize with the aims of the research. The respondents are 30, 10 respondents in each district.

\subsection{Qualitative Descriptive Analysis}

This method is used to characterize and identify the respondents and their home industry such as name, age, gender, education, work ownership and place, assets 
and income. They are very important to describe clearly the conditions of the respondents so then the researchers will be easier in formulating the problems based on the the objective and significance of the study (Sugiyono, 2013)

\subsection{Validity test and Reliability}

Validity test and reliability of the data are done to get measurable data to be analyzed. Validity test is measured by comparing $r$ table and $r$ count from a research. If $r$ count is bigger than $r$ table, then it is valid. In vise versa, if $r$ count is smaller than $r$ table, then it is invalid. Meanwhile, reability test is measured by comparing Cronbach's Alpha and minimum measure 0,6 if Cronbach's Alpha is under 0,6 then it is unreliable but if Cronbach's Alpha is more than 0,6 so it is reliable (Santoso, 2012)

\subsection{Double Linear Regression Analysis}

Double linear regression analysis is a linear relationship between 2 or more independent variables $\left(X_{1}, X_{2}, \ldots X_{n}\right)$ and dependent variable $(\mathrm{Y})$.

This analysis is used to know if the relationship between independent and dependent variables are positive or negative and to predict the value in the variables. Data used is usually in scale of interval or ratio. The formula of double linear regression as follow:

$$
Y^{\prime}=\mathbf{a}+\mathbf{b}_{1} \mathbf{X}_{1}+\mathbf{b}_{2} \mathbf{X}_{2}+\mathbf{b}_{3} \mathbf{X}_{3}
$$

Explanation :

$\mathrm{Y}^{\prime}=$ Featured Product of Rural area in Pamekasan

$\mathrm{X} 1=$ Labour quality

$\mathrm{X} 2$ = management Skill

X3 = Proses Input dan Output

$\mathrm{a}=$ constanta (value $\mathrm{Y}^{\prime}$ if $\mathrm{X}_{1}, \mathrm{X}_{2} \ldots . . \mathrm{X}_{\mathrm{n}}=0$ )

$\mathrm{b}=$ coefficient of regression (value of

increase or decrease)

\section{RESULT AND DISCUSSION}

\subsection{Result}

\subsubsection{Identification of Respondent and Business}

Identification of respondent is an important part because it clarifies the condition of the respondent related to this research. The respondents are the owners of the featured product of rural area in Pamekasan. In this research, the respondents are categorized into age, gender, education, and occupation.

Age is one of factors which influence one's mindset in fulfilling the questionnaires. It means, the respondent must be in productive age to answer the questionnaire to get reliable response. Based on the questionnaires, there are 30 respondents in this research. They are:

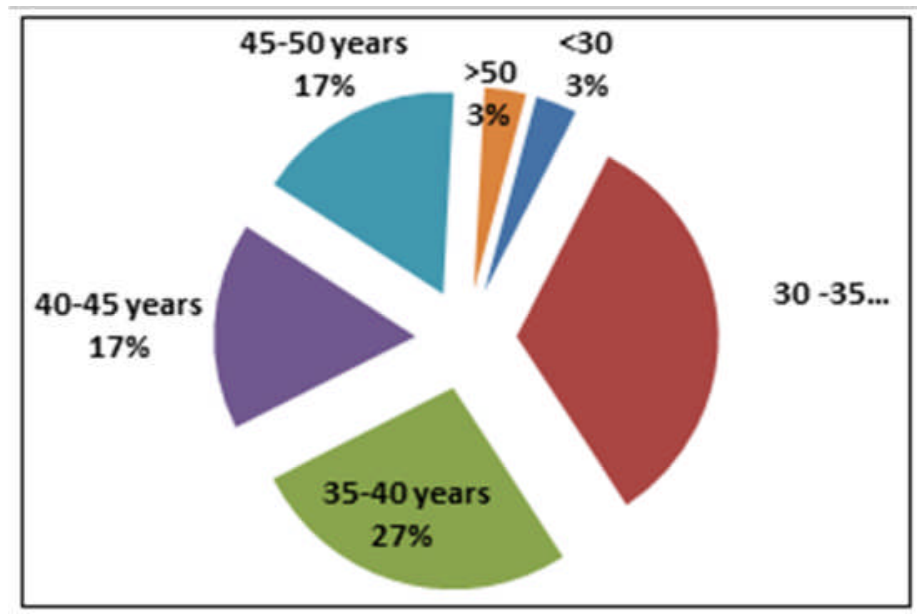

Picture 1. Characteristic of Respondents Based on Age Source : the result of questionnaires 2019 
The picture above shows that the age of the respondents are averagely productive: $33 \%$ is $30-35$, $27 \%$ is $35-40$ and $17 \%$ is $40-50$ and $3 \%>50$ and $<30$.

The gender of the respondents shows that $73 \%$ is female and $27 \%$ is male :

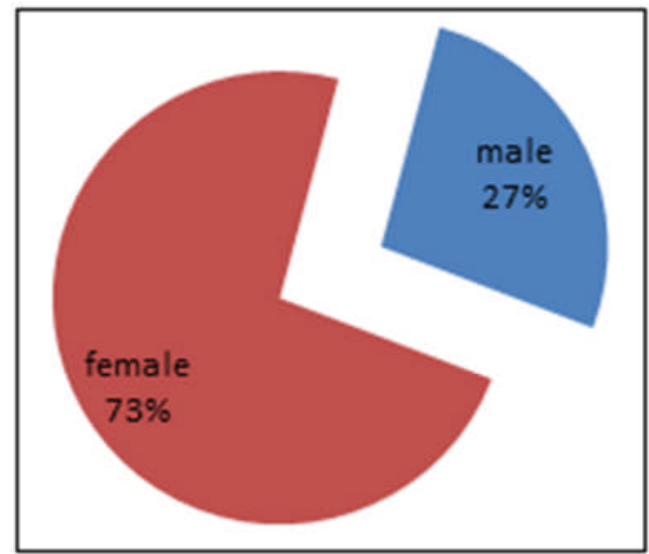

Picture 2. Characteristic of Respondents Based on Gender Source : the result of questionnaires. 2019

Based on the education, the respondent are educated enough so then they can respond the questionnaires well. Fifty percents of them graduated from Islamic boarding school, thirty three percents unfinished their elementary school and the rest accomplished their elementary school

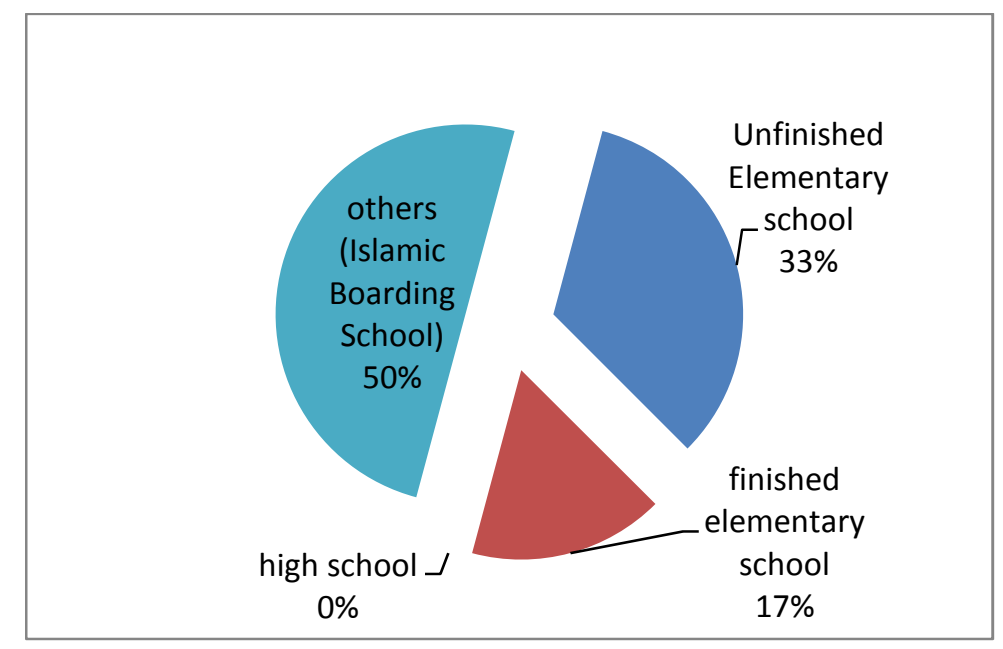

Picture 3. Characteristic of Respondents Based on Education Source : the result of questionnaires. 2019

In average, businessman in Pamekasan are entrepreneurs whose assets are around Rp. 50.000.000 and the incomes are less than Rp. 50.000.000 and the customers are mostly non-residents of Pamekasan.

\subsubsection{Test of Validity and Reliable Data}

Test of validity is measured test for reputability. Form some elements and questions in the questionnaires, validity test is done by comparing $r$ count from $r$ table, if $r$ count is $>$ than $r$ table so that it is valid; in vice versa, if $r$ count $<$ than $r$ table so it is invalid.

$$
\begin{aligned}
\mathbf{r} \text { table } & =\mathbf{d f}=\mathbf{N}-\mathbf{2} \\
\mathrm{df} & =30-2=28 \\
& =0.3610
\end{aligned}
$$


Table 1 Test of Validity

\begin{tabular}{|c|l|c|c|}
\hline \multirow{2}{*}{ NO } & \multicolumn{1}{|c|}{ VARIABLE } & $\begin{array}{c}\text { PEARSON CORRELATION/ } \\
\text { r Count }\end{array}$ & \multirow{2}{*}{ Result } \\
\hline 1 & Y (PRUKADES) & 1,000 & VALID \\
\hline 2 & X1 (Labour quality) & 0,499 & VALID \\
\hline 3 & X2 (Management skill) & 0,472 & VALID \\
\hline 4 & X3 (Process of Input dan Output) & 0,746 & VALID \\
\hline
\end{tabular}

Because $r$ count is $>$ than $r$ table so it is valid.

Reability test is measured by comparing Cronbach's Alpha and minimum measure 0,6 if Cronbach's Alpha is under 0,6 then it is unreliable but if Cronbach's Alpha is more than 0,6 so it is reliable. Table 2 is the

result.

Table 2 Reability Test

\begin{tabular}{|r|r|}
\hline \multicolumn{2}{|c|}{ Reliability Statistics } \\
\hline $\begin{array}{c}\text { Cronbach's } \\
\text { Alpha }\end{array}$ & N of Items \\
\hline .770 & 4 \\
\hline
\end{tabular}

The picture above shows that value of Cronbach's Alpha is 0,77 or $>$ than 0,6 . So it is valid.

\subsection{Discussion}

\subsubsection{Prukades (Featured Product of Rural Area) in Increasing Home Industry Productivity in n Pamekasan}

The progress of featured product of rural area in Pamekasan is influenced by home industry productivity. The more productive then the more advance the product. The indicators are :

$$
\begin{aligned}
& \text { X 1 }=\text { Labour quality } \\
& \text { X2 }=\text { Management skill } \\
& \text { X3 }=\text { Process of Input dan Output }
\end{aligned}
$$

That is, the higher labour quality, management skill and process of input and output (home industry productivity/X) the advance the featured product of rural area in Pamekasan (Y). to comprehend the relationship between 2 variables $X$ (Home Industry Productivity) and Y (Featured Product), it needs to analyze double linear regression by using SPSS :

\section{Double correlation Analysis Korelasi (R) and Determination (RSquare)}

Double Correlation Analysis ( $\mathrm{R})$ is used to understand the relationship between variable $\mathrm{X}$ (Home Industry Productivity) consists of indicators X1 (Labour quality), X2 (Management skill), X3 (Process of Input dan Output) and Y (Featured Product of rural area in Pamekasan). Value $\mathrm{R}$ is around 0 to 1 , if the value reaches 1 means the relationship gets stronger. In vice versa, if the value reaches 0 means the relationship gets weaker. This is the guidance:

$$
\begin{aligned}
& 0,00-0,199=\text { very low/weak } \\
& 0,20-0,399=\text { low/weak } \\
& 0,40-0,599=\text { moderate } \\
& 0,60-0,799=\text { strong } \\
& 0,80-1,000 \quad=\text { very strong } \\
& \text { Sugiyono, 2013) }
\end{aligned}
$$

From the result of regression analysis, the output model summary is displayed as follow: 
Tabel 3. Double Correlation Analysis (R)

\begin{tabular}{|l|c|c|c|c|}
\hline \multicolumn{5}{|c|}{ Model Summary } \\
\hline Model & R & R Square & $\begin{array}{c}\text { Adjusted R } \\
\text { Square }\end{array}$ & $\begin{array}{l}\text { Std. Error of } \\
\text { the Estimate }\end{array}$ \\
\hline 1 & $.800^{\text {a }}$ & .640 & \multicolumn{2}{c|}{.599} \\
\hline $\begin{array}{l}\text { a. Predictors: (Constant), X3_Output_input, X1_labour quality, } \\
\text { X2_management skill }\end{array}$ \\
\hline \multicolumn{3}{|l|}{ b. Dependent Variable: Y_PRUKADES } \\
\hline
\end{tabular}

Based on the table above $\mathrm{R}$ is 0,800 . It means the relationship is very strong. Determination (RSquare) or determination in double linear regression is used to know the percentage between the impact of independent variable $X$ (Home Industry Productivity) consists of X1 (labour quality), X2 (management skill), and X3 (Process of Input dan Output) simultaneously and dependent variable $\mathrm{Y}$ (featured product of rural area in Pamekasan). If RSquare(R2) is 0 , so there is no impact percentage given by variable $\mathrm{X}$ to $\mathrm{Y}$, if $\mathrm{R} 2$ equals 1 , then the percentage impact given by $\mathrm{X}$ to $\mathrm{Y}$ is perfect ( $100 \%)$. In picture 4.2 the value of RSquare is $64,0 \%$. it means the impact given by X X1 (labour quality), X2 (management skill), and $\mathrm{X} 3$ (Process of Input and Output) to $\mathrm{Y}$ (featured product of rural area in Pamekasan) is $64,0 \%$. the rest is $36,0 \%$ influenced by other factors excluded this research.

\section{Regression Coefficient Test Simultaneously (Test F)}

This test is used to know if the independent variable $\mathrm{X}$ (Home Industry Productivity) consists of X1 (labour quality), $\mathrm{X} 2$ (management skill), and X3 (Process of Input and Output) simultaneously will influence significantly to dependent variable $\mathrm{Y}$ (featured product of rural area in Pamekasan), or to know if regression model can be used to predict dependent variable. From the output, is known that $\mathrm{F}$ is like in table 4.5 :
$\mathrm{H} 0=$ there is no relationship between $(\mathrm{X})$ and (Y)

$\mathrm{H} 1$ = there is relationship between $(\mathrm{X})$ and (Y)

Tabel 4 ANOVA

\begin{tabular}{|c|c|c|c|c|c|c|}
\hline \multicolumn{7}{|c|}{ ANOVA $^{a}$} \\
\hline \multicolumn{2}{|c|}{ Model } & Sum of Squares & $\mathrm{df}$ & Mean Square & & Sig. \\
\hline \multirow[t]{3}{*}{1} & Regression & 137.940 & 3 & 45.980 & 15.420 & $.000^{\mathrm{b}}$ \\
\hline & Residual & 77.526 & 26 & 2.982 & & \\
\hline & Total & 215.467 & 29 & & & \\
\hline
\end{tabular}

\section{Criteria}

Ho is accepted if $\mathrm{F}$ count $<\mathrm{F}$ table

Ho is rejected if $\mathrm{F}$ count $>\mathrm{F}$ table

From test of Anova gets $\mathbf{F}$ count is 15,420

if $\mathrm{F}$ count $>\mathrm{F}$ table $(15,420>2,87)$, so Ho is rejected, in this case there is relationship between Home Industry Productivity (X) and the increase of features product of rural area in Pamekasan (Y). If Home Industry Productivity increases, so the

\section{F Table}

df $1=$ sum of variable $-1=3$

df $2=\mathrm{n}-\mathrm{k}-1=30-3-1=36$

so $\mathrm{F}$ table $=2,87$

featured product of rural in Pamekasan will increase.

\section{Regression Coefficient Test Partially (Test t)}

This test is used to know if regression model $(\mathrm{X})$ partially will impact 
significantly to Pamekasan (Y). This is the output:

Table 6. Coefficients

\begin{tabular}{|c|c|c|c|c|c|c|}
\hline \multirow{2}{*}{\multicolumn{2}{|c|}{ Model }} & \multicolumn{2}{|c|}{ Unstandardized Coefficients } & \multicolumn{3}{|l|}{$\begin{array}{l}\text { Standardized } \\
\text { Coefficients }\end{array}$} \\
\hline & & $\mathrm{B}$ & Std. Error & Beta & $\mathrm{t}$ & Sig. \\
\hline 1 & (Constant) & 21.414 & 3.487 & & 6.141 & .000 \\
\hline & X1_Labour quality & .756 & .308 & .304 & 2.457 & .021 \\
\hline & X2_Management Skill & -.031 & .149 & -.032 & -.208 & .837 \\
\hline & X3_Output_input & .965 & .222 & .675 & 4.346 & .000 \\
\hline
\end{tabular}

Dependent Variable: Y_PRUKADES

Hypotesis

Ho : Partially, there is no significant impact between home industry productivity (X) and the progress of featured product of rural area in Pamekasan (Y).

Ha : Partially, there is a significant impact between home industry productivity (X) and the progress of featured product of rural area in Pamekasan (Y).

Level of significance uses a $=5 \%$

$\mathbf{t}$ count Based on table, it gets $t$ count as 0,6141

$\mathbf{t}$ table on $\mathrm{a}=5 \%: 2=2,5 \%$ (test in 2 sides) with degree free (df) n-k-1 or 30-2-1 $=27=0.3673$

\section{Test Criteria}

Ho is received if $-\mathrm{t}$ table $<\mathrm{t}$ count $<\mathrm{t}$ table Ho is denied if $-\mathrm{t}$ count $<-\mathrm{t}$ table or $\mathrm{t}$ count $>$ $\mathrm{t}$ table

Therefore, if the value of $\mathrm{t}$ count $<\mathrm{t}$ table $(0,6141<0.3673)$ so $\mathrm{Ha}$ is received. That is, partially there is significant impact between home industry productivity (X) and the progress of featured product of rural area in Pamekasan (Y). Or if home productivity increases then featured product of rural area in Pamekasan will increases as well.

\section{CONCLUSION}

Based on the research, the respondents are the owner of the featured products of rural area in Pamekasan and in the productive age: $33 \%$ are $30-35,27 \%$ are $35-40$. from 30 respondents, $73 \%$ are female so they are more persistent, discipline and careful. They mostly graduated from Islamic boarding school, around $50 \%$. Islamic boarding school (pesantren) is a common school attended by Madurese girls. In average, the have business that are managed by themselves, so besides the owners they are also the workers. The assets is less then Rp. 50.000.000 and the income is less then Rp. 50.000.000 with the market target is outside Pamekasan.

Based on statistic analysis, validity test is valid because $r$ count is bigger than $r$ table. From reliability, it is measured that the value of Cronbach's Alpha is 0,77 or bigger than 0,6. The result of double linear regression analysis is $\mathrm{R} 0,800$. Thus, the relationship between independent variables $(\mathrm{X})$ and dependent variable $(\mathrm{Y})$ is strong. The influence impact is $64,0 \%$ while the rest, $36,0 \%$, is influence by other variable excluded in this research.

In whole, $\mathrm{F}$ test (simultaneous regression coefficient test) There is relationship between home industry productivity $(\mathrm{X})$ and the increase of featured product of rural area in Pamekasan (Y) because $\mathrm{F}$ count $>\mathrm{F}$ table $(15,420>2,87)$. That is, if home industry productivity increases, the featured products get improved too. Meanwhile partially ( $t$ test), there is significant impact between home industry productivity $(\mathrm{X})$ and the increase of featured product of rural area in Pamekasan (Y) because $t$ count $<\mathrm{t}$ table $(0,6141<0.3673)$. 


\section{REFERENCES}

Daryanto (2012). Pendidikan Kewirausahaan. Malang: Gava Media

Fahrurrozi (2016.) Paradigma Ekonomi Islam Terhadap Konsep Marketing. Jurnal Ekonomi Syari'ah \& Bisnis Islam Vol 3 No 1

Hasibuan (2005). Manajemen Sumber Daya Manusia Edisi Revisi. Jakarta: PT. Bumi Aksara

Kementrian Desa PDPT (2019). Produk Unggulan Kawasan Pedesaan. http://prukades.kemendesa.go.id/lp age/

Nurman (2015). Strategi Pembangunan Daerah. Cetakan ke-1. Jakarta: PT. RajaGrafindo Persada

Peraturan Menteri Desa (2015). Pembangunan Daerah Tertinggal, dan Transmigrasi Nomor 3 Tahun 2015 tentang Pendampingan Desa, Pasal 1 Ayat 9
Rahardjo, A. (2006). Pembangunan Pedesaan dan Perkotaan. Yogyakarta: Graha Ilmu,

Santoso, S. 2012. Panduan Lengkap SPSS Versi 20. Jakarta: PT Elex Media Komputindo.

Siti Susana, S. (2012). Peranan Home Industri Dalam Meningkatkan Kesejahteraan Masyarakat Menurut Perspektif Ekonomi Islam(Studi Kasus Desa Mengkirau Kecamatan Merbau) (Skripsi). Universitas Islam Negeri Sultan Syarif Kasim Riau

Sugiyono. (2013). Metodelogi Penelitian Kuantitatif, Kualitatif Dan $R \& D$. Bandung: ALFABETA

Sumaryadi. (2005). Perencanaan Pembangunan Daerah Otonom dan

Pemberdayaan Masyarakat. Jakarta, Citra Utama.

Wignjosoebroto, S. (2000). Tata Letak Pabrik dan Pemindahan Bahan (Edisi 1). Jakarta: Penerbit PT Guna Widya 